\title{
A Preliminary Checklist of Vascular Plants in Tarak Ridge trail of Mt. Mariveles, Bataan, Philippines
}

\author{
Shiela L.Vidallon',3,* \& Axel H.Arriola ${ }^{1,2}$ \\ ${ }^{1}$ The Graduate School, University of Santo Tomas, España, Manila 1015, Philippines; email: shiela.vidallon@cvsu.edu.ph \\ ${ }^{2}$ Department of Biological Sciences, College of Arts and Sciences, University of the East, 2219 C.M. Recto Ave, \\ Manila, Philippines \\ ${ }^{3}$ Department of Teacher Education, Cavite State University-Carmona Campus, Market Road Carmona, Cavite, Philippines \\ "Corresponding author, e-mail: shiela.vidallon@cvsu.edu.ph
}

\begin{abstract}
Mount Mariveles is a potentially active stratovolcano and is one of the remaining forests in Bataan province that is under threat due to different anthropogenic factors. A checklist is essential for it and it will give baseline information on the species and their conservation status. This study aimed to provide a preliminary checklist of vascular plants at Tarak ridge (Mariveles trail) in Mt. Mariveles, Bataan. A belt transect was established at Tarak ridge trail from 400 meters above sea level (m asl) to $1000 \mathrm{~m}$ asl. Each transect has three plots of $10 \mathrm{~m} \mathrm{x} 10 \mathrm{~m}$. A total of 80 species belonging to 50 families and 74 genera were documented in this study. Poaceae family had the most numbered genera. Of the 80 flora species inventoried, 35 are shrubs, trees are 17, herbs are 14, 11 are epiphytes and 3 are vines. Among the 80 recorded flora, five species were endemic in the Philippines. Only three species were assessed for their conservation status based in IUCN categories and were assessed as Least concern. Two endemic species from Rubiaceae family, the Psychotria luzoniensis (Cham. \& Schltdl.) Fern.-Vill was assessed as Least Concern while Psychotria rubiginosa Elmer ex Merr was originally assessed as Nearthreatened but in a recent study it was assessed as Data Deficient (DD).
\end{abstract}

KEY WORDS Forest fire; GIS; Lardjem; NDVI; Regeneration; remote sensing; Checklist; endemic; floristic.

Received 17.12.2021; accepted 16.07.2021; published online 04.11.2021

\section{INTRODUCTION}

A regional assessment made by the Intergovernmental Science-Policy Platform on Biodiversity and Ecosystem Services (IPBES, 2018) reported that biodiversity is declining in all regions of the world. According to the U.S. Agency for International Development (USAID, 2014), the estimated biodiversity loss is about 1000 species each year due to uncontrollable legal and illegal human activities. The highest rate of deforestation is in Southeast Asia. It loses its original area by 2100 , which is about $78 \%$, and its biodiversity has been projected up to $42 \%$ (Sodhi et al., 2010).
The Philippines is one of the countries with rich biodiversity, but it is a hotspot due to the rapid loss (Philippine Biodiversity Conservation Priorities, 2002). It has only $3 \%$ of the land area covered by primary forests (Myers et al., 2000), putting the current biodiversity at extreme risk (Langerbeger et al., 2006).

It lost $1.4 \%$ or 89,000 hectares of the forest area annually from 1990-2000 (FAO, 2003). Even with the extraordinary status of the Philippines as one of the world's 25 biodiversity hotspots (Myers et al., 2000; Brooks et al., 2006; Webb et al., 2010) as well as the threats of environmental destruction, the country's remaining forests and their biodiversity are poorly 
represented in research (Langerberger, 2004). Historically, biodiversity hotspots are mostly insufficient in scientific reports and taxonomy (Cowling et al., 2010; Grieneisen, 2014) and distinct in achieving inventories comprehensively on different species (Sobral \& Stehmann, 2009; Ferzza \& Baumgratz, 2012). In previous years, most of the plant survey studies focused on the qualitative list of species, while quantitative studies on plant inventories for the Philippines are still relatively scarce (Villanueva \& Buot, 2015; Santiago \& Buot, 2017; Ordas et al., 2019). According to the study of Alsherif \& Fadl (2016) and Yates et al. (2019) floristic surveys are important because these would help in proper monitoring and development of effective conservation strategies.

Bataan's significant features such as being an "industrial heartland", a "prime business hub", and a major transshipment point in Central Luzon (Provincial Government of Bataan and Partnership in Environmental Management for the Seas (PEMSEAS), 2017), contributed to the threat of biodiversity due to pollution and land conversion, leading to the destruction of plants and animals, especially in the forested areas in the Province. Mt. Mariveles, a potentially active stratovolcano, Philippine Institute of Volcanology and Seismology (Phivolcs, 2013), the highest mountain in Bataan with 1388 meters above sea level (m asl) (Bataan ICM Program, 2006) and one of the remaining forests in Bataan province (Balila et al., 2012), is under threat due to different anthropogenic factors. It has two trails, the Pantingan Peak and Tarak ridge.

The Tarak ridge is a well-known destination for mountaineers because it is one of Manila's major climbs. It is poorly explored in plant inventory and diversity, so meager information is available about plants' list and status in the Tarak ridge trail. There were different studies on inventory and diversity assessment of plants that were conducted in Luzon but the availability of flora inventory lacks in Mt. Mariveles, Bataan. Before the depletion of biodiversity in the said mountain due to different anthropogenic factors, an inventory of vascular plants should be conducted to generate knowledge on their checklist. Hence, this study aims to provide a preliminary checklist of vascular at Tarak ridge (Mariveles trail) in Mt. Mariveles, Bataan.

\section{MATERIAL AND METHODS}

\section{Study area}

Mt. Mariveles (1430 N, $120^{\circ} 30$ E) (Fig. 1) has 23,688 hectares. An area of forest is characterized as lowland, mossy forest and montane. This area includes an old-growth forest of Mt. Mariveles and old reforestation plantation in former Lamao Arsenal (PAWB-DENR, 2005).

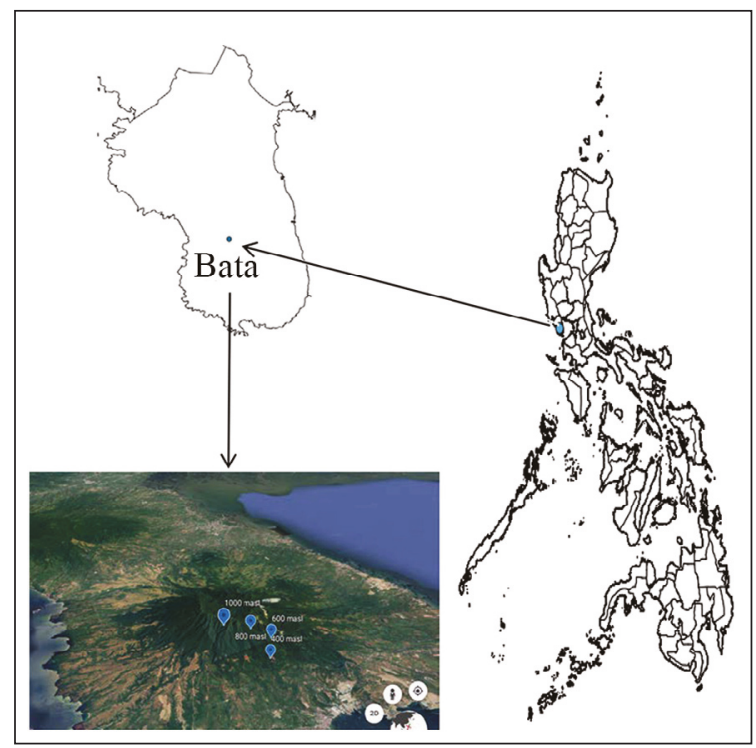

Figure 1. Map of the Philippines showing Bataan province where Mt. Mariveles is located generated using QGIS 1.7.4. Areas surveyed are marked in blue. (Mt. Mariveles map. http://earth.google.com).

It has two trails, the Mt. Mariveles trail (Tarak ridge) (Figs. 2-5) in Brgy. Alasasin, Mariveles and Bagac trail (Pantingan Peak) in Bagac. Bataan has a distinct climate, a dry and wet season and has Type I climate classification in the Coronas system. The rainy season begins in May to October, while the dry season is from November to April. The maximum rains occur from June to August. The mean average rainfall in August is most torrential at $633 \mathrm{~mm}$.

\section{Plant collection and identification}

The plant collections/inventory was conducted last October 2019 to March 2020. A belt transect was established at Tarak ridge trail from 400 meters above sea level ( $\mathrm{m}$ asl) to $1000 \mathrm{~m}$ asl. The 

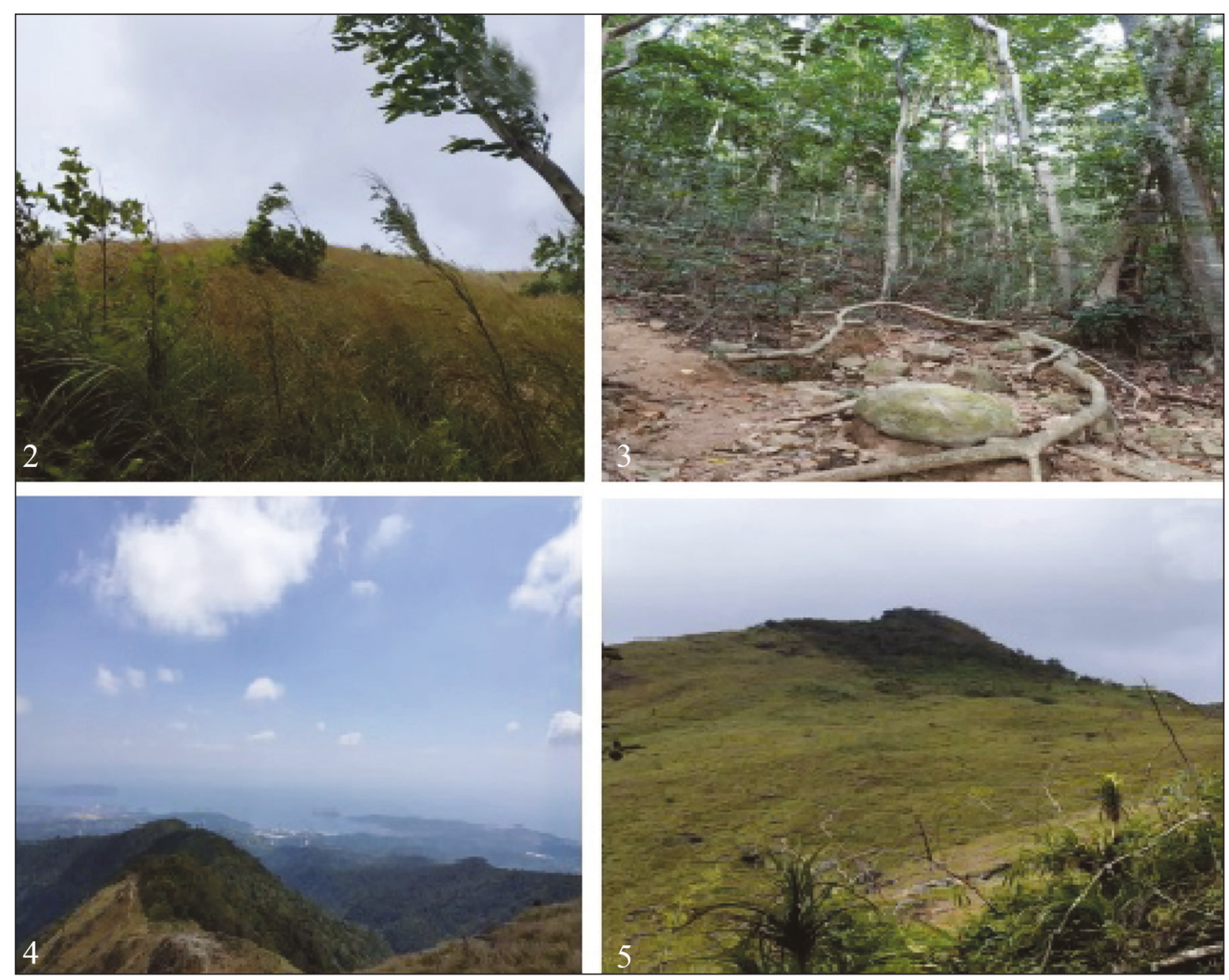

Figures 2-5. The Tarak ridge trail. Fig. 2: grassland area. Fig. 3: forest area. Fig. 4: Tarak ridge. Fig. 5: peak of Tarak ridge (photos taken by S. Vidallon).

transect was $10 \mathrm{~m} \times 100 \mathrm{~m} \log$ with longer width beyond the gradient and shorter width on the elevation gradient. Each transect has three plots of $10 \mathrm{~m}$ x $10 \mathrm{~m}$. Plants on their reproductive stages were collected for precise identification of species. The specimens were processed for herbarium, and the vouchers specimen was submitted at the University of Santo Tomas Herbarium. There is no database on the information about the flora of $\mathrm{Ba}$ taan thus the specimens were compared to Co's Digital Flora of the Philippines (Pelser et al., 2011) and compared to the digital herbarium specimen of the Herbarium Catalogue of Royal Botanic Gardens, Kew (http://www. kew.org). The plants conservation status was based on the Updated National List of Threatened Plants in the Philippines (Department of Environment and Natural Resources
Administrative Order 2017-11) and the International Union for the Conservation of Nature (IUCN) Red List of Threatened species 2020-2. The specimens were verified by the University of the Philippines curators, Los Banos Museum of Natural History, Laguna.

\section{Conservation Status and Endemicity}

The conservation status of the plants was determine based on the categories from the IUCN Red List of Threatened Species (2020-2) and the Department of Environment and Natural Resources (DENR) - Administrative Order No. (DAO) 201711 (2017). The species were categorized as NE = Not Evaluated, DD = Data deficient, OT $=$ Other Threatened Species, LC = Least Concern, V = Vul- 
nerable, $\mathrm{EN}=$ Endangered, $\mathrm{CR}=$ Critically endangered), $\mathrm{E}=$ Philippine endemic, $\mathrm{N}=$ non-endemic .

\section{RESULTS}

Mostly agriculturals crops were observed at lower elevation, 400 meters above sea level (m asl). An agricultural crop like Ananas comosus (pineapple) was planted in the area (Fig. 6-9). The species of fruit trees were also observed such as Sandoricum koetjape (santol), Artocarpus heterophyllus (jackfruit) and Mangifera indica (Mangga) (Figs. 10-29). Gmelina arborea, was also recorded in $400 \mathrm{~m}$ asl (Fig. 10).

The observed plants were evidence of conversion of a mountain into agricultural lands. Calamus usitatus and Acacia auriculiformis were also observed in one of the plots in the same elevation. At a higher elevation, $600 \mathrm{~m}$ asl, the grassland area was observed and it was dominated by the grass species, Imperata cylindrica (Cogon). Imperata exists in quite large contiguous areas in the said elevation. The medium-sized trees, Syzygium sp., Ecalyptus sp. and Ficus septica were also observed in the grassland vegetation (Fig. 10). While doing the transect walk within the same elevation going to the campsite near Papaya river, different plant species were recorded, and some of these were: Aristolochia sp., Begonia sp., Brucea mollis, Anaxagorea luzonensis, Coleus scutellarioides., and Sarcandra glabra (Fig. 20). Different ferns were also observed at the same elevation like Leptochilus ellipticus and Microsorum longissimum. They were mostly located adjacent to the water source where there are high
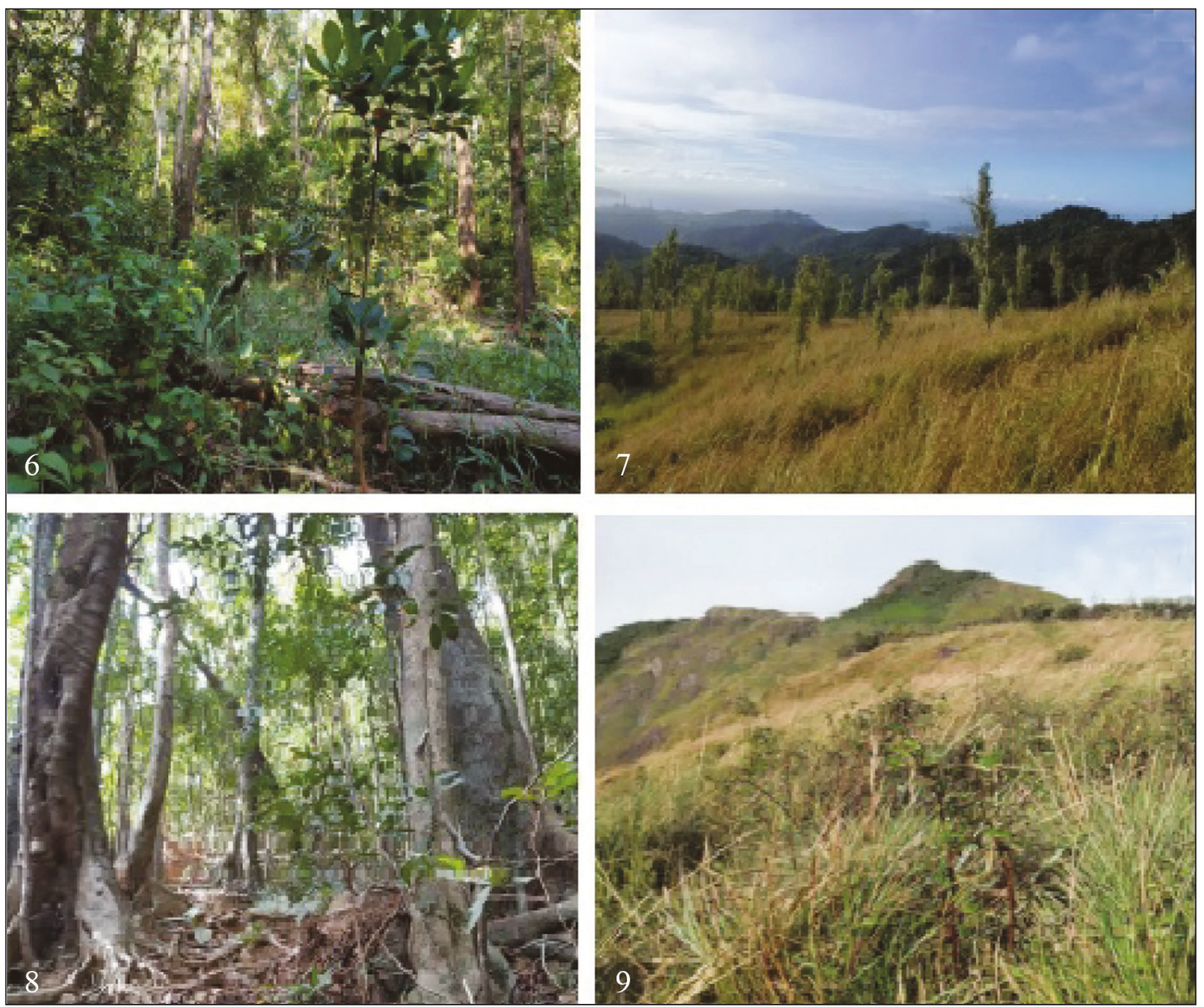

Figures 6-9. The study sites at Tarak ridge trail in Mt. Mariveles. Fig. 6: agricultural land at $400 \mathrm{~m}$ asl. Fig. 7: grassland area at $600 \mathrm{~m}$ asl. Fig. 8: forest area at $800 \mathrm{~m}$ asl. Fig. 9: grassland area at $1000 \mathrm{~m}$ asl (photos taken by S. Vidallon). 


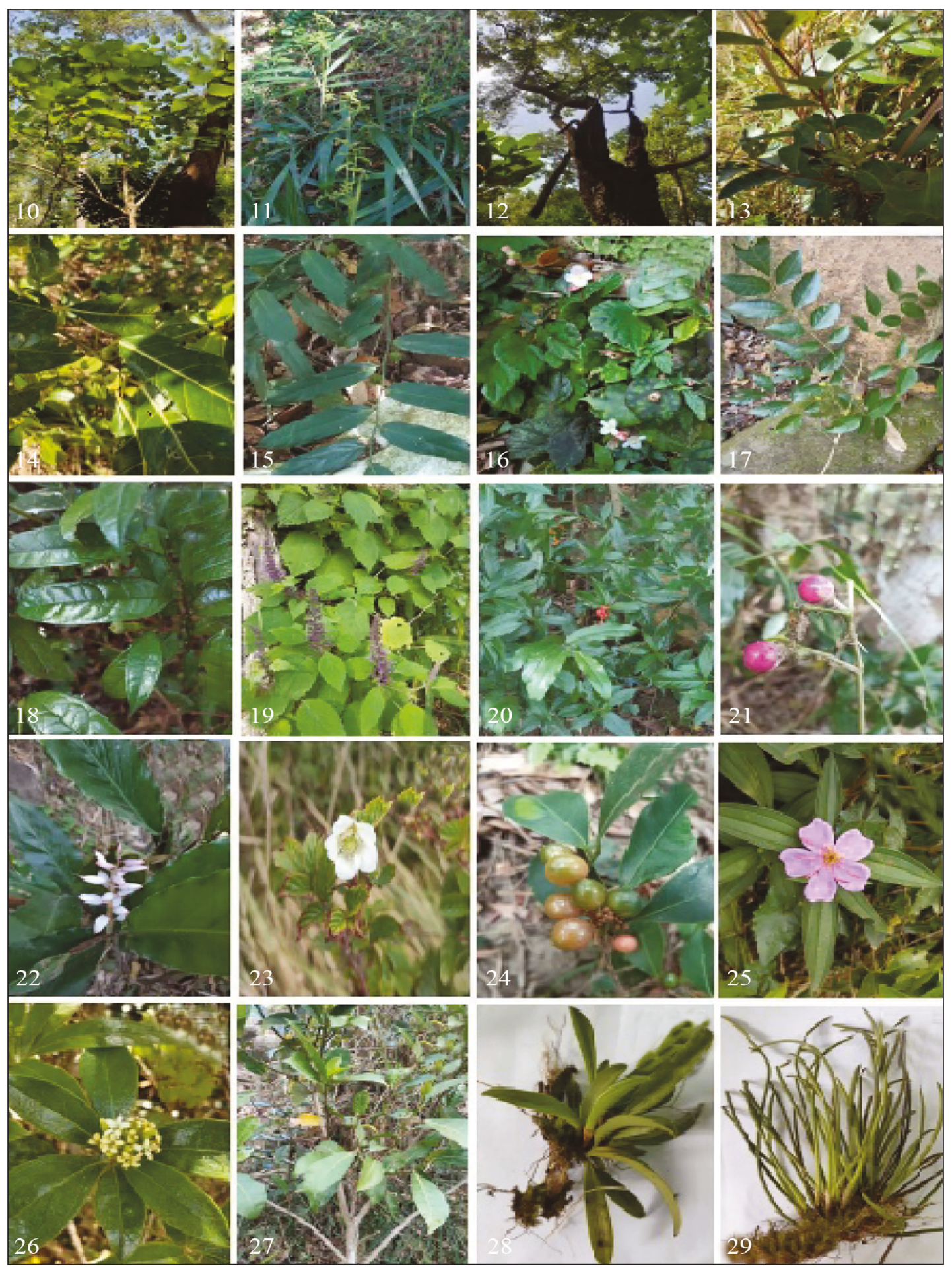

Figures 10-29. Some of the recorded plants at Tarak ridge of Mt. Mariveles. Figs. 10-12: plants observed at $400 \mathrm{~m}$ asl. Fig. 10: Gmelina arborea. Fig. 11: Calamus usitatus. Fig. 12: Acacia auriculiformis. Figs. 13-20: plants observed at $600 \mathrm{~m}$ asl. Fig. 13: Syzygium sp. Fig. 14: Ficus septica. Fig. 15: Aristolochia sp. Fig. 16: Begonia sp. Fig. 17: Brucea mollis. Fig. 18: Anaxagorea luzonensis. Fig. 19: Coleus scuttellaroides. Fig. 20: Sarcandra glabra Figs. 21-22: plants observed at $800 \mathrm{~m}$ asl. Fig. 21: Angyreia barnesii. Fig. 22: Alpinia haenkeni. Figs. 23-24: plants observed at $1000 \mathrm{~m}$ asl. Fig. 23: Rubus fraxinipolius. Fig. 24: Glycosmis parviflora. Figs. 25-29: plants observed at the peak. Fig. 25: Melastoma malabathricum. Fig. 26: Pittosporum ferrigeneum. Fig. 27: Ficus sp. Fig. 28: Bulbophyllum sp. Fig. 29: Ceratolystys sp. (photos taken by S. Vidallon). 

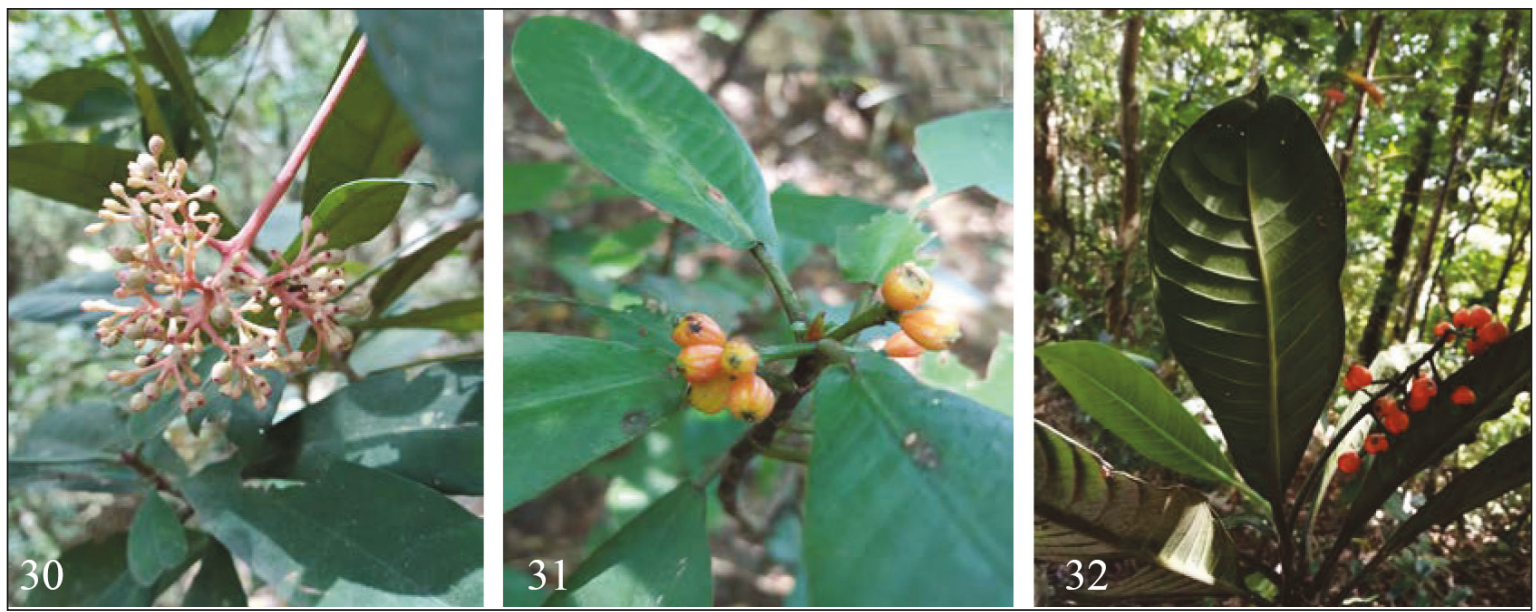

Figures 30-32. The fruiting branches of three Endemic Rubiaceae species. Fig. 30: Ixora macrophylla.

Fig. 31: Psychotria luzoniensis. Fig. 32: Psychotria rubiginosa (photos taken by S. Vidallon).

moisture and shade. A shrub Psychotria luzoniensis (Figs. 30-32), was also observed at 600 and $1000 \mathrm{~m}$ asl while doing a transect walk. At the very steep, hilly part of the mountain ( $800 \mathrm{~m}$ asl), forest area, the height and the presence of very large buttressed trees like Dipterocarpus sp. can be observed. The understory comprises fewer species and fewer families than the canopy layer. Some observed plants at the said elevation were: the shrubs, Ixora macrophylla, Psychotria rubiginosa (Fig. 32), Angyreia barnesii (vine) and an herb, Alpinia haenkei (Fig. 22). At the mountain top, in $1000 \mathrm{~m}$ asl, Imperata cylindrica was also the dominant species. Imperata also exists in quite large contiguous areas in the said elevation but no tree species were observed within the grassland vegetation but a shrub was observed in the said vegetation and this was Rubus fraxinipolius (Fig.

\begin{tabular}{|lccc|}
\hline \multirow{2}{*}{ Plant Groups } & \multicolumn{3}{c|}{ Total Number of } \\
\cline { 2 - 4 } & Families & Genera & Species \\
\hline Shrubs & 20 & 32 & 35 \\
Trees & 12 & 16 & 17 \\
Herbs & 8 & 13 & 14 \\
Epiphytes & 7 & 10 & 11 \\
Vines & 3 & 3 & 3 \\
\hline Total & 50 & 74 & 80 \\
\hline
\end{tabular}

Table 1. Taxonomic inventory of flora at Tarak ridge trail in Mt. Mariveles, Bataan.
23). The trees observed in one of the three plots at the same elevation was Glycosmis parviflora (Fig. 24).

During the transect walk going to the peak of the Tarak ridge other species were recorded, these were the shrubs, Melastoma malabathricum and Pittosporum ferrugineum, a tree species, Ficus sp. and epiphytes, Bulbophyllum sp. and Ceratostilys sp. (Fig. 29).

The preliminary data reveals 80 species of flora belonging to 50 families and 74 genera were recorded at Tarak ridge trail in Mt. Mariveles, Bataan. Of the 80 flora species inventoried, 35 are shrubs, 17 are trees, 14 are herbs, 11 are epiphytes and 3 are vines (Table 1). Among the 80 species recorded, 32 are ornamentals, 20 are ecosystems services, 13 are medicinal plants, 7 are crop-food, 5 are weeds and 3 are crop-wood. The Angiosperm family having the most number genera is Poaceae (7), followed by Lamiaceae and Asteraceae with 5 genera each. The rest of the plant families have three or fewer species. A total of 5 species recorded were endemic in the Philippines. These are Angyreia barnesii (Convolvulaceae), Psychotria luzoniensis, Psychotria rubiginosa and Ixora marcophylla (Rubiaceae) and Brucea mollis (Simiroubaceae) (Table 2). There were eight (8) species of pteridophytes belonging to six (6) families and seven (7) genera. Among the pteridophytes, Polypodiaceae family had two species, while the rest had one species each.

Out of 80 plant species recorded at Tarak ridge 


\begin{tabular}{|c|c|c|c|c|c|}
\hline Family & Species & Local Name & Habit & Endemicity & $\begin{array}{l}\text { Conservation } \\
\text { Status } \\
\text { DENR - IUCN }\end{array}$ \\
\hline Acanthaceae & Strobilanthes sp. & & $\mathrm{S}$ & $\mathrm{N}$ & $\mathrm{NE}$ \\
\hline Anacardiaceae & $\begin{array}{l}\text { Mangifera indica } \\
\text { L. (1753) }\end{array}$ & Mangga & $\mathrm{T}$ & $\mathrm{N}$ & $\mathrm{NE}$ \\
\hline Anonaceae & $\begin{array}{l}\text { Anaxagorea } \\
\text { luzonensis A.Gray (1854) }\end{array}$ & & $\mathrm{T}$ & $\mathrm{N}$ & NE \\
\hline Anonaceae & $\begin{array}{l}\text { Phaeanthus ophthalmicus } \\
\text { (Roxb. Ex G Don) J. Sinclair } 1955\end{array}$ & & $\mathrm{~T}$ & $\mathrm{~N}$ & NE \\
\hline Apocynaceae & $\begin{array}{l}\text { Tabernaemontana - } \\
\text { pandacaqui Poir. } \\
\text { in Lam (1806) }\end{array}$ & Kampupot & $\mathrm{T}$ & $\mathrm{N}$ & $\mathrm{NE}$ \\
\hline Aquifoliaceae & $\begin{array}{l}\text { Ilex asprella } \\
\text { (Hook. And Arn.) } \\
\text { Champ ex Benth (1908) }\end{array}$ & & $\mathrm{S}$ & $\mathrm{N}$ & $\mathrm{NE}$ \\
\hline Araceae & $\begin{array}{l}\text { Aglaonema } \\
\text { commutatum Schott (1856) }\end{array}$ & & $S$ & $\mathrm{~N}$ & $\mathrm{NE}$ \\
\hline Araceae & Aglaonema sp. & & $\mathrm{S}$ & & \\
\hline Arecaceae & $\begin{array}{l}\text { Caryota cumingii } \\
\text { Lodd. ex C.Mart (1853) }\end{array}$ & Ubod & $\mathrm{T}$ & $\mathrm{N}$ & $\mathrm{NE}$ \\
\hline Arecaceae & $\begin{array}{l}\text { Calamus usitatus } \\
\text { Blanco, Fl. Filip (1837) }\end{array}$ & & $\mathrm{T}$ & $\mathrm{N}$ & $\mathrm{LC}$ \\
\hline Aristolochiaceae & Aristolochia sp. & & $\mathrm{S}$ & & \\
\hline Aspleniaceae & Asplenium sp. & & $\mathrm{E}$ & $\mathrm{N}$ & NE \\
\hline Asteraceae & $\begin{array}{l}\text { Chromolaena } \\
\text { odorata (L.) (1907) } \\
\text { R.M.King \& H.Rob }\end{array}$ & & S & $\mathrm{N}$ & $\mathrm{NE}$ \\
\hline Asteraceae & Senecio sp. & & $S$ & & \\
\hline Asteraceae & $\begin{array}{l}\text { Gynura vidaliana } \\
\text { Elmer }(1906)\end{array}$ & & $\mathrm{S}$ & $\mathrm{N}$ & NE \\
\hline Asteraceae & $\begin{array}{l}\text { Mikania cordata } \\
\text { (Burm.f.) B.L.Rob. (1934) }\end{array}$ & & $\mathrm{V}$ & $\mathrm{N}$ & $\mathrm{NE}$ \\
\hline Asteraceae & $\begin{array}{l}\text { Pseudelephantopus } \\
\text { spicatus (Juss.) Rohr (1792) }\end{array}$ & & $\mathrm{H}$ & $\mathrm{N}$ & $\mathrm{NE}$ \\
\hline Athryriaceae & $\begin{array}{l}\text { Athyrium } \\
\text { drepanopterum } \\
\text { (Kunze) A. Br. Ex } \\
\text { Milde (1867) }\end{array}$ & & $\mathrm{E}$ & $\mathrm{N}$ & $\mathrm{NE}$ \\
\hline Begoniaceae & Begonia sp. & & $\mathrm{H}$ & & \\
\hline Bromeliaceae & $\begin{array}{l}\text { Ananas comosus } \\
\text { (L.) Merr (1917) }\end{array}$ & Pinya & $\mathrm{H}$ & $\mathrm{N}$ & $\mathrm{NE}$ \\
\hline Celastraceae & Salacia $\mathrm{sp}$ & & $S$ & & \\
\hline Chloranthaceae & $\begin{array}{l}\text { Sarcandra glabra } \\
\text { (Thunb.) (1930) }\end{array}$ & & $\mathrm{S}$ & $\mathrm{N}$ & $\mathrm{NE}$ \\
\hline Convolvulaceae & $\begin{array}{l}\text { Argyreia barnesii } \\
\text { Merr. var. Barnesii (1950) }\end{array}$ & & $\mathrm{V}$ & $\mathrm{E}$ & $\mathrm{NE}$ \\
\hline Crassulaceae & Kalanchoe sp. & & $\mathrm{H}$ & & \\
\hline Cyperaceae & $\begin{array}{l}\text { Bolboschoenus } \\
\text { fluviatilus (Torr). } \\
\text { Sojak (1972) }\end{array}$ & & $\mathrm{H}$ & $\mathrm{N}$ & $\mathrm{NE}$ \\
\hline Dipterocarpaceae & Dipterocarpus sp. & & $\mathrm{T}$ & & \\
\hline Euphorbiaceae & Croton sp. & & $\mathrm{S}$ & & \\
\hline Euphorbiaceae & $\begin{array}{l}\text { Excoecaria } \\
\text { philippinensis Merr.(1906) }\end{array}$ & & $\mathrm{S}$ & $\mathrm{N}$ & NE \\
\hline Fabaceae & $\begin{array}{l}\text { Acacia } \\
\text { auriculiformis } \\
\text { A.Cunn. ex Benth (1842) }\end{array}$ & Auri & $\mathrm{T}$ & $\mathrm{N}$ & NE \\
\hline
\end{tabular}




\begin{tabular}{|c|c|c|c|c|c|}
\hline Lamiaceae & $\begin{array}{l}\text { Gmelina arborea } \\
\text { Roxb. ex Sm (1810) }\end{array}$ & Gmelina & $\mathrm{T}$ & $\mathrm{N}$ & $\mathrm{NE}$ \\
\hline Lamiaceae & $\begin{array}{l}\text { Achyrospermum } \\
\text { densiflorum Blume (1826) }\end{array}$ & & $\mathrm{S}$ & $\mathrm{N}$ & $\mathrm{NE}$ \\
\hline Lamiaceae & $\begin{array}{l}\text { Coleus scuttelarioides } \\
\text { (L.) Benth (1830) }\end{array}$ & & $\mathrm{S}$ & $\mathrm{N}$ & NF \\
\hline Lamiaceae & Pogostemon sp. & & $\mathrm{S}$ & & \\
\hline Lamiaceae & $\begin{array}{l}\text { Clerodendrum } \\
\text { japonicum (Thunb.) (1826) }\end{array}$ & & $\mathrm{S}$ & $\mathrm{N}$ & NE \\
\hline Lygodiaceae & $\begin{array}{l}\text { Lygodium flexuosum } \\
\text { (L) Sw (1800) }\end{array}$ & & $\mathrm{E}$ & $\mathrm{N}$ & NE \\
\hline Melastomataceae & $\begin{array}{l}\text { Melastoma } \\
\text { malabathricum L.(1753) }\end{array}$ & & $\mathrm{S}$ & $\mathrm{N}$ & $\mathrm{NE}$ \\
\hline Meliaceae & $\begin{array}{l}\text { Sandoricum koetjape } \\
\text { (Burm.f.) Merr (1912) }\end{array}$ & Santol & $\mathrm{T}$ & $\mathrm{N}$ & $\mathrm{LC}$ \\
\hline Moraceae & $\begin{array}{l}\text { Artocarpus } \\
\text { heterophyllus Lam (1789) }\end{array}$ & Langka & $\mathrm{T}$ & $\mathrm{N}$ & $\mathrm{NE}$ \\
\hline Moraceae & $\begin{array}{l}\text { Ficus sp. } \\
\text { Merr.(1904) }\end{array}$ & & $\mathrm{T}$ & & \\
\hline Moraceae & $\begin{array}{l}\text { Ficus septica } \\
\text { Burm.f. (1768) }\end{array}$ & & $\mathrm{T}$ & $\mathrm{N}$ & $\mathrm{NE}$ \\
\hline Myrtaceae & Syzygium sp. & & $\mathrm{T}$ & & \\
\hline Myrtaceae & Eucalyptus sp. & & $\mathrm{T}$ & & \\
\hline Nephrolepidiaceae & $\begin{array}{l}\text { Nephrolepis } \\
\text { cordifolia (L) } \\
\text { C. Presl. (1836) }\end{array}$ & & $\mathrm{E}$ & $\mathrm{N}$ & $\mathrm{NE}$ \\
\hline Orchidaceae & Coelogyne sp. & & $\mathrm{E}$ & & \\
\hline Orchidaceae & Ceratostilys sp. & & $\mathrm{E}$ & & \\
\hline Orchidaceae & Bulbophyllum sp. & & $\mathrm{E}$ & & \\
\hline Pandanaceae & Pandanus sp. & & S & & \\
\hline Pentaphragmataceae & Pentaphragma sp. & & $\mathrm{H}$ & & \\
\hline Phyllanthaceae & $\begin{array}{l}\text { Breynia androgyna L. } \\
\text { Chakrab. \& N.P.Balakr (2012) }\end{array}$ & & $\mathrm{S}$ & $\mathrm{N}$ & $\mathrm{NE}$ \\
\hline Phyllanthaceae & Cleisanthus sp. & & $\mathrm{S}$ & & \\
\hline Phyllanthaceae & $\begin{array}{l}\text { Breynia-vitis idaea } \\
\text { (Burm.f.) C.E.C. (1932) }\end{array}$ & & $\mathrm{S}$ & $\mathrm{N}$ & $\mathrm{NE}$ \\
\hline Pipperaceae & Piper sp. & & $\mathrm{V}$ & $\mathrm{N}$ & $\mathrm{NE}$ \\
\hline Pittosporaceae & $\begin{array}{l}\text { Pittosporum } \\
\text { ferruginaeum W.T. Aiton (1811) }\end{array}$ & & $\mathrm{S}$ & $\mathrm{N}$ & NE \\
\hline Poaceae & $\begin{array}{l}\text { Cyrtococcum patens } \\
\text { (L) A. Camus (1921) }\end{array}$ & & $\mathrm{H}$ & $\mathrm{N}$ & $\mathrm{NE}$ \\
\hline Poaceae & Agrostis sp. & & $\mathrm{H}$ & & \\
\hline Poaceae & $\begin{array}{l}\text { Pogonatherum crinitum } \\
\text { (Thunb.)Kunth (1833) }\end{array}$ & & $\mathrm{H}$ & $\mathrm{N}$ & $\mathrm{NE}$ \\
\hline Poaceae & $\begin{array}{l}\text { Panicum maximum } \\
\text { Jacq. }(1781)\end{array}$ & & $\mathrm{H}$ & $\mathrm{N}$ & $\mathrm{NE}$ \\
\hline Poaceae & $\begin{array}{l}\text { Imperata cylindrica } \\
\text { (L) Raeusch (1812) }\end{array}$ & Kogon & $\mathrm{H}$ & $\mathrm{N}$ & $\mathrm{NE}$ \\
\hline Poaceae & Bambusa sp. & & $\mathrm{S}$ & & \\
\hline Polypodiaceae & $\begin{array}{l}\text { Leptochilus ellipticus } \\
\text { (Thunb.) Noot (1977) }\end{array}$ & & $\mathrm{E}$ & $\mathrm{N}$ & $\mathrm{NE}$ \\
\hline Polypodiaceae & Leptochilus sp. & & $\mathrm{E}$ & & \\
\hline Polypodiaceae & $\begin{array}{l}\text { Microsorum longissimum } \\
\text { J.Sm. (1947), }\end{array}$ & & $\mathrm{E}$ & $\mathrm{N}$ & $\mathrm{NE}$ \\
\hline Pteridaceae & $\begin{array}{l}\text { Adiantum diaphanum } \\
\text { Blume (1828) }\end{array}$ & & $\mathrm{E}$ & $\mathrm{N}$ & $\mathrm{NE}$ \\
\hline Rubiaceae & $\begin{array}{l}\text { Psychotria rubiginosa } \\
\text { Elmer ex Merr (1906) }\end{array}$ & & $\mathrm{S}$ & $\mathrm{E}$ & $\mathrm{DD}$ \\
\hline Rubiaceae & $\begin{array}{l}\text { Psychotria luzoniensis } \\
\text { (Cham. \& Schltdl.) } \\
\text { Fern.-Vill (1880) }\end{array}$ & & $\mathrm{S}$ & $\mathrm{E}$ & $\mathrm{LC}$ \\
\hline
\end{tabular}




\begin{tabular}{|c|c|c|c|c|}
\hline Rubiaceae & Ixora macrophylla Bartl. (1830) & $\mathrm{S}$ & $\mathrm{E}$ & $\mathrm{NE}$ \\
\hline Rosaceae & Rubus fraxinifolius Poir (1806) & $\mathrm{S}$ & $\mathrm{N}$ & NE \\
\hline Rutaceae & $\begin{array}{l}\text { Glycosmis parviflora } \\
\text { (Sims.) Little (19408) }\end{array}$ & $\mathrm{S}$ & $\mathrm{N}$ & $\mathrm{NE}$ \\
\hline Sapindacaceae & Allophylus sp. & $\mathrm{T}$ & & \\
\hline Simiroubaceae & $\begin{array}{l}\text { Brucea mollis Wall } \\
\text { ex. Kurz (1873) }\end{array}$ & $\mathrm{S}$ & $\mathrm{E}$ & $\mathrm{NE}$ \\
\hline Sparmanniaceae & Grewia laevigata Vahl. (1790) & $\mathrm{S}$ & $\mathrm{N}$ & $\mathrm{NE}$ \\
\hline Stemonuraceae & $\begin{array}{l}\text { Codiocarpus merrittii } \\
\text { (Merr.) (1943) }\end{array}$ & $\mathrm{T}$ & $\mathrm{N}$ & $\mathrm{NE}$ \\
\hline Taccaceae & Tacca palmata Blume (1827) & $\mathrm{S}$ & $\mathrm{N}$ & $\mathrm{NE}$ \\
\hline Thymelaceae & $\begin{array}{l}\text { Wikstroemia lanceolata } \\
\text { Merr.(1905) }\end{array}$ & $\mathrm{S}$ & $\mathrm{N}$ & $\mathrm{NE}$ \\
\hline Urticaceae & $\begin{array}{l}\text { Pipturus arborescens } \\
\text { (Link) C.B.Rob (1911) }\end{array}$ & $\mathrm{S}$ & $\mathrm{N}$ & $\mathrm{NE}$ \\
\hline Verbenaceae & Lantana camara L. (1753) & $\mathrm{S}$ & $\mathrm{N}$ & $\mathrm{NE}$ \\
\hline Vitaceae & Leea philippinensis Merr. 1906 & $\mathrm{~S}$ & $\mathrm{~N}$ & $\mathrm{NE}$ \\
\hline Zingiberaceae & Атотит sp. & $\mathrm{H}$ & & \\
\hline Zingiberaceae & $\begin{array}{l}\text { Alpinia cf. aquatica } \\
\text { Roscoe } 1807\end{array}$ & $\mathrm{H}$ & $\mathrm{N}$ & $\mathrm{LC}$ \\
\hline Zingiberaceae & Alpinia haenkei C.Presl (1832) & $\mathrm{H}$ & $\mathrm{N}$ & $\mathrm{NE}$ \\
\hline
\end{tabular}

Table 2. Preliminary checklist of flora at Tarak ridge trail in Mt. Mariveles, Bataan. Plant families are arranged alphabetically followed by species of each family, Habit $(\mathrm{T}=$ tree, $\mathrm{S}=$ shrub, $\mathrm{H}=$ herb, $\mathrm{V}=$ vine, $\mathrm{E}=$ epiphyte), conservation status based on IUCN Red List of Threatened Species or the DENR Administrative Order (DAO) 2017-11 (NE = Not Evaluated, DD = Data deficient, OT $=$ Other Threatened Species, $\mathrm{LC}=$ Least Concern, $\mathrm{V}=$ Vulnerable, $\mathrm{EN}=$ Endangered, $\mathrm{CR}=\mathrm{Critically}$ endangered), endemicity based on Pelser et al., (2011-onwards) $(\mathrm{E}=$ Philippine endemic, $\mathrm{N}=$ non-endemic).

trail in Mt. Mariveles, only two plant species were evaluated for their conservation status based on IUCN and DENR category. Sandoricum koetjape of Meliaceae family, Calamus usitatus and Alpinia cf. aquatica assesed by IUCN as the Least concern. Psychotria rubiginosa (Rubiaceae) was originally assessed by Sohmer \& Davis (2007) as Near-threatened but in the recent study of Biag \& Alejandro (2020), it was assessed as Data Deficient (DD). According to them, it requires further surveys for additional distributional data while Psychotria luzoniensis was also assessed by Sohmer \& Davis (2007) as Least Concern.

The endemicity of collected flora was based on Co's digital flora of the Philippines by Pelser et al. (2011). Only $6.25 \%$ of all species identified were endemic in the Philippines. All the recorded species from the Rubiaceae family are endemic in the Philippines (Figure 5). Among the five endemic species recorded, two species from the Rubiaceae family, Psychotria rubiginosa and P. luzoniensis (Fig. 4) were also assessed based on its conservation status.

\section{DISCUSSION}

Altitude, slope, latitude, aspect, rainfall and humidity play a role in forming plant communities and their composition. (Kharwall et al., 2005). The lower elevation (400 $\mathrm{m}$ asl) in Tarak ridge is being limited to agroforestry practices based on the species observed at the said elevation. According to the forest guide/local resident, some landowners converted their lands within the mountain into agricultural land. The fruit trees and crops observed at the said elevation were evidence for the said practices. Gmelina arborea Roxb., an introduced species (Villegas \& Pollisco, 2008) recorded at the same elevation, is a fast-growing fire-resistant timber tree promoted by national and regional government institutions and used in the local furniture industry (Snelder, 2001). Acacia auriculiformis Benth planted at the same elevation, is a fast growing plantation species for pulp and timber production and multipurpose used in tropical Asia. Its importance as plantation species can be attributed to rapid-growth, compared to the quality of the wood and tolerance to a range 
of soil types and $\mathrm{pH}$ values (Yamamoto et al., 2003). At 600 and $1000 \mathrm{~m}$ asl of the mountain, Imperata cylindrica (known locally as cogon) were the dominant species. In the Philippines, the most common form of vegetation in the uplands is grassland, predominantly Imperata cylindrica (known locally as cogon) (Garrity, et al., 1997). Imperata cylindrica may exists in quite large contiguous areas or small patches in a vegetation mosaic with shrubs or cropped fields (Garrity, et al.,1997). The former was observed in grassland area at Tarak ridge. At the turn of $20^{\text {th }}$ century, $40 \%$ of Luzon island and extensive areas of other Philippine islands were covered with grassland. The land classification of 1919 estimated that grassland covered $19 \%$ of the entire country, a figure that stayed roughly constant through 1957 (Roth, 1983). Imperata cylindrica alone covers 35 million hectares throughout the region. These grasslands are important to some people living around them that use them for grazing animals or for shifting cultivation. Still, they generally provide few benefits relative to the lands' potential productivity (FAO, 2010). In the Philippines, the large areas of grasslands were converted to agricultural, resulting in the decline of the net area of grassland (Garrity et al., 1993). According to the residents, the grassland area at $600 \mathrm{~m}$ asl was recently cleared, for it will be planted with Pterocarpus indicus by private entities. The government is promoting the establishment of tree plantations by private entities as well as permanent reforestation activities using their assisted natural regeneration (ANR) technique where usually fast-growing tree species such as Gmelina arborea, Acacia mangium, Pterocarpus indicus and Eucalyptus sp. are planted (Lasco \& Pulhin, 2000). ANR is a forest restoration and rehabilitation practice that is successfully using Imperata cylindrica (L.) Raeusch and other grassdominated areas to convert them into productive forests. This effective technique relies on the natural process of plant succession. It is used for fire prevention and management, control of grazing, suppression of grasses and nurturing seedlings and sapling of indigenous trees (FAO, 2010). At $800 \mathrm{~m}$ asl, forest area with dominant tree species was observed with some shrubs, herbs and vines recorded. The understory comprises fewer species than the canopy layer.

Among the 80 recorded species at Tarak ridge in Mt. Mariveles, Poaceae family are the dominant species. It was predominated by Imperata cylindrica
(Cogon), a perennial grasses of low forage quality (Snelder, 2001) specifically found at 600 and 1000 $\mathrm{m}$ asl in the said mountain. Poaceae is the fifth most-species rich family of flowering plants (Hodkinson \& Parnell, 2007a, b; The Plant List, 2013). This family is also ecologically dominant, covering grasslands or bamboo forests approximately $40 \%$ of the Earth's land surface (Gibson, 2008). Grasses are the most important plant group, providing our staple cereals such as Eragrostis, Hordeum, Oryza, Secale, Sorghum, Triticum, and Zea; sugar crops such as Saccharum and Sorghum; reeds such as Arundo and Phragmites; and bamboo for food, building, and amenity materials such as Bambusa and Phyllostachys (Clayton \& Renvoize, 1986; Hodkinson et al., 2000). Lamiaceae family with five recorded genera at Tarak ridge is one of the largest families among the dicotyledons and is the most diverse and widespread plant families in terms of ethnomedicine with many species that are highly aromatic due to the presence of external grandular structures that produce volatile oil (Sarac \& Ugur, 2007; Guiliani \& Bini, 2008). Asteraceae family or sunflower family, with also five recorded genera at Tarak ridge, consists of 1911 genera and 32,205 species wordlwide (Royal Botanic Gardens Kew and Missouri Botanic Garden, 2019). The members of the family of Asteraceae are distributed in every continent but Antartica (Funk et al., 2005).

Only seven $(6.5 \%)$ of the recorded plants were endemic in the Philippines. Three recorded species from Rubiaceae family were all endemic in the Philippines. Among these three species, $P$. rubiginosa is endemic in the Philippines but mainly in Luzon and was found in Divilacan, Isabela (Biag \& Alejandro, 2020). It was also recorded in Cebu (Sohmer and Davis, 2007). Two endemic species from the Rubiaceae family, the Psychotria rubiginosa was originally assessed as Near-threatened (Sohmer and Davis, 2007) but in the recent study it was assessed as Data Deficient (DD) (Biag \& Alejandro, 2020) while Psychotria luzoniensis was assessed as Least Concern (Sohmer \& Davis, 2007). According to Williams et al. (1996), endemicity is defined as the state of having a limited geographic range, which could be confined to an area or to a country. Endemic species characteristics such as restricted distribution, one or few populations, small population size, declining population size, excessive collection by humans, short reproduction capacity, specific habitat conditions, and necessity of stable and con- 
stant environment make them more vulnerable than others to anthropogenic threats and extinction (Isik, 2011). These endemic species should be carefully monitored and managed, and their conservation should be considered a global priority (Isik, 2011; Fogi et al., 2014).

Anthropogenic disturbances have played a role in modifying vegetation in tropical forests of the Philippines (Sopsop \& Buot 2013), which lead to observable changes in land use along elevational gradients in most of the country's mountains. Different threats to the mountain's biodiversity were observed during botanical exploration, such as charcoal production and honey collecting. Said activities can be destructive to the natural resources of the forest. The upgrade of the unmaintained earthen road to the mountain also could give the locals easy access to the mountain that might cause overexploitation of its natural resources. Since the Tarak ridge is one of the well-known destinations for mountaineers as one of the major climbs near Manila, an increase in the number of tourists/mountaineers poses a threat to the mountain as undisciplined mountaineers left their garbage in the campsite. The guide was the one who picked up the trash that they left. Papaya river is near the campsite and the water in this river is potable. It is also the source of water for the residents at the foot of the mountain, so protection strategies and conservation law should be created and implemented to protect and preserve its natural resources even though it is not a protected area.

\section{CONCLUSIONS}

A series of field visits at Tarak ridge in Mt. Mariveles reveals 80 species of vascular plants dominated by Poaceae family. There were five endemic species in the recorded flora. Among the documented flora, only three species were assessed based on their conservation status by IUCN. The IUCN assessed three species as Least concern. Two endemic species from the Rubiaceae family, one was recently assessed as Near-threatened while the other was assessed as Least Concern. Different threats to biodiversity were encountered during the conduct of the study, these were the production of charcoal, collecting of honey, the upgrade of unmaintained road going to the mountain and the undisciplined tourists/mountaineers that throw their garbage on the mountain. Protection and conserva- tion strategies should be created and implemented to protect and preserve its natural resources.

\section{ACKNOWLEDGMENTS}

The first author is grateful to the Commission on Higher Education and Cavite State University for the grant and scholarship. We are thankful to the locals for helping and being the guide during collections. We also acknowledge the Department of Environment and Natural Resources for the gratuitous permit that allow us to collect plants.

\section{REFERENCES}

Alsherif E.A. \& Fadl M.A., 2016. Floristic study of the Al-Shafa highlands in Taif, Western Saudi Arabia. Flora, 225: 20-29. https://doi.org/10.1016/j.flora.2016.09.004

Balilla V.S., Anwar-McHenry J., McHenry M.P., Parkinson R.M. \& Banal D.T., 2012. Aeta Magbukún of Mariveles: Traditional Indigenous Forest Resource Use Practices and the Sustainable Economic Development Challenge in Remote Philippine Regions, Journal of Sustainable Forestry, 31: 687709.

Bataan ICM Program, Project Management Office, 2006. The Bataan Sustainable Development Strategy.

Biag R.D. \& Alejandro G.J.D., 2020. Short Communication: Rediscovery of Psychotria species, subspecies, and varieties collected in the 1990s and new records of Antirhea benguetensis (Elmer) in Northern Sierra Madre Natural Park, Luzon, Philippines. Biodiversitas, 21: 4524-4535. https://doi.org/10.13057/biodiv/d211059

Brooks T.M., Mittermeier R.A., Da Fonseca Gab., Gerlach J., Hoffman M., Lamoreux J.F., Mittermeier C.G., Pilgrim J.D. \& Rodrigues A.S.L., 2006. Global biodiversity conservation priorities. Science, 313: 58-61.

Brown R., Silver C., Oliveros C., Esselstyn J., Diesmos A., Hosner P., Alcala A. et al., 2013. Evolutionary processes of diversification in a model island archipelago. Annual Review of Ecology, Evolution, and Systematics 44: 138-150.

https://doi.org/10.1146/annurevecolsys-110411-160323

Clayton W.D. \& Renvoize S.A., 1986. Genera Graminum: Grasses of the World. UK: Royal Botanic Gardens. HMSO Books.

Cowling R.M., Knight A.T., Privett S.D.J. \& Sharma G., 2010. Invest in opportunity not inventory of hotspots. Conservation Biology, 24: 663-635. 
DENR-PAWB CI \& UP-CIDS, 2003. Philippine Biodiversity Conservation Priorities: A Second Iteration of the Naional Biodiversity Strategy and Action Plan. 113 pp. Department of Environment and Natural Resources and the United Nations Environment Programme. Bookmark, Inc., Makati, Philippines.

Food and Agriculture Organization, 2010. Key findings. Forest resource assessment.

FAO, 2003. State of the World's Forests 2003. FAO, Rome, Italy. www.fao.org/DOCREP/005/ Y7581E/ Y7581E00.HTM, accessed 25 February 2004.

Foggi B., Viciani D., Baldini R.M., Carta A. \& Guidi T., 2014. Conservation assessment of the endemic plants of the Tuscan Archipelago, Italy. Orix, 49: 118-126.

Forzza R. \& Baumgratz J., 2012. New Brazilian floristic list highlights conservation challenges. Bioscience, 62: 39-45.

Funk V.A., Bayer R.J., Keeley S., Chan R., Watson L., Gemeinholzer B., Schilling E.E., Panero J.L., Baldwin B.G., Garcia-Jacas N.T., Susanna A. \& Jansen R.K., 2005. Everywhere but Antarctica: Using a supertree to understand the diversity and distribution of the Compositae. Biologiske Skrifter, 55: $343-$ 374.

Gairola S., Rawal R.S. \& Todaria N.P., 2008. Forest vegetation patterns along an altitudinal gradient in sub-alpine zone of West Himalaya, India. African Journal of Plant Science, 2: 42-48.

Garrity D.P., Kumer D.M. \& Guiang E.S., 1993. Sustainable agriculture and the environment in the humid tropics: the Philippines, In: Sustainable and the Environment, pp. 449-624. National Academy Press, Washington, DC, USA.

Garrity D.P., Soekardi M., Van Noordwijk M., Dela Cruz R., Pathak P.S., Gunasena H.P., Van So N., Huijun G. \& Majid N.M., 1997. The Imperata grasslands of Tropical Asia. Area, distribution and typology. Agroforestry Systems, 36: 3-29

Gibson D.J., 2008. Grasses and Grassland Ecology. UK: Oxford University Press.

Grieneisen, M.L., Zhan, Y., Potter, D. and Zhang, M. 2014. Biodiversity taxonomic infrastructure international collaboration and new species discovery. Bioscience, 64: 322-332.

Guilian C. \& Maleci Bini, 2008. Insight into the structure and chemistry of glandular trichomes of Labiatae, with emphasis on subfamily Lamioideae. Plant Systematic and Evolution, 276: 199-208.

Heaney L. \& Regalado J.C. Jr., 1998. Vanishing Treasures of the Philippine Rain Forest: A Comprehensive Introduction to the Biodiversity of the Philippines. The Field Museum University of Chicago Press, Chicago, $88 \mathrm{pp}$.

Herbarium Catalogue of Royal Botanic Gardens, Kew. https://www.kew.org.
Hodkinson T.R., Renvoize S.A., Chonghaile G.N. et al., 2000. A comparison of ITS nuclear rDNA sequence data and AFLP markers for phylogenetic studies in Phyllostachys (Bambusoideae, Poaceae). Journal of Plant Research, 113: 259-269.

Hodkinson, T.R. \& Parnell, J.A.N., 2007a. Introduction to the systematics of species rich groups. In: Hodkinson T.R. \& Parnell J.A.N. (Eds.), Reconstructing the Tree of Life: Taxonomy and Systematics of Species Rich Taxa, pp. 3-20. FL: CRC Press.

Hodkinson T.R. \& Parnell J.A.N., 2007b. Reconstructing the Tree of Life: Taxonomy and Systematics of Species Rich Taxa. Boca Raton, FL: CRC Press, $351 \mathrm{pp}$.

IPBES, 2018. Summary for policy makers of the regional assessment report on biodiversity and ecosystem services for Asia and the Pacific of the Intergovernmental Science Policy Platform on Biodiversity and Ecosystem Services. M, Karki, S. Semaratna Sellamutu, S. Okajasa, W. Suzuki, L.A. Acosta, Y. Alhafedh, J.A. Anticamara, A.G. Ausseil, K. Davies, A gasparatos, H. Gundimela, I. Faridha-Hanuman, R. Kohsaka, R. Kumar, S. Managi, N. Wu, A. Rajvanshi, G.S. Rawat, P. Riordan, S. Shrama, A. Virk, C. Wang, T. Yahara and Y.C. Youn (ed). IPBES Secretariat, Bonn, Germany, pp.41.

Isik K., 2011. Rare and endemic species: Why are they prone to extinction? Turkish Journal of Botany, 35: 411-417.

IUCN, The IUCN Red List of Threatened Species. Version 2020-2. Available online: http://www.iucnredlist.org (accessed on October 2020).

Kharwal G., Mehretra P., Rawat Y.S. \& Pangtey Y.P.S., 2005. Phytodiversity and growth form in relation to altitudinal gradient in the Central Himalayan (Kumaun) region of India. Current Science, 89: 873-878.

Langenberger G., Martin K. \& Sauerborn J., 2006. Vascular plant species inventory of Philippine lowland rainforest and its conservation value. Biodiversity and Conservation, 15: 1271-1301. https://doi.org/10.1007/ s10531-005-2576-4

Langerberger G., 2004. A review of research on Philippine forest vegetation, particularly work since 1990. Agham Mindanaw, 2004, Vol. 2, pp. 11-24. Ateneo de Davao University.

Lasco R.D. \& Pulhin F.B., 2000. Forest land-use change in the Philippines and climate change mitigation. Mitigation and adaptation to Global change Journal: 5: 81-97

Medicillo M.M.P. \& Lagat M.N., 2017. Floristic composition of the remaining forests in Upland, Cavite, Luzon Island, Philippines. Philippine Journal of Systematic Biology, 11: 74-92.

Mt. Mariveles map, 2021. http://earth.google.com 
Myers N., Mittermeier R.A., Mittermeier C.G., da Fonseca G.A.B. \& Kent J., 2000. Biodiversity hotspots for conservation priorities. Nature, 403: 853-858.

Ordas J.A.D., Pinarok N.A.A., Romeroso R.B., Alejandro G.J.D. \& Banag-Moran C.I., 2019. A checklist of Rubiaceae species from Eastern Samar, Visayas, Philippines. Check List 15: 295-302.

Pelser P.B., Barcelona J.F. \&, Nickrent D.L. (Eds.), 2011 onwards. Co's Digital Flora of the Philippines. www.philippineplants.org

PEMSEA and Provincial Government of Bataan, Philippines. (2017). State of the Coasts of Bataan Province. Partnerships in Environmental Management for the Seas of East Asia (PEMSEA), Quezon City, Philippines.

Phivolcs, 2013. Philippine Institute of Volcanology and Seismology List of Potentially Active and nactive Volcanoes. Available online at http://www.phivolcs. dost.gov.ph.

RBG Kew, 2016. The state of the world's plants report 2016. Royal Botanic Garden, Kew.

Roth D.M., 1983. Philippine forest and forestry: 15651920. In: Tucher R.P. \& Richards J.R. (Eds.), Global Deforestation and the nineeteent Century world economy, pp 30-49. Duke University Press, Durham NC, USA.

Royal Botanic Gardens Kew and Missouri Botaic Garden, 2019. The Plant List: "Compositae". Downloaded from http://www.theplantlist.org/1.1/browse/A/Co mpositae/ on 08-14-2019.

Santiago J.O \& Buot I.E., 2015. Conservation status of selected plants of Mount Banahaw, San Cristobal Protected Landscape, Quezon Province Philippines. International Journal of Ecology and Conservation, 16: 64-79.

Santiago J.O. \& Buot, I.E., 2017. Checklist of Hoya species on Palawan Island. Philippine Journal of Systematic Biology, 16: 34-44.

Sarac N. \& Ugur A., 2007. Antimicrobial activities and usage in folkloric medicine of some Lamiaceae species growing in Mugla Turkey. EurAsian Journal of BioSciences, 1: 28-34.

Snelder D.J., 2001. Forest patches in Imperata grasses and prospects for their preservation under agricultural intensification in Northeast Luzon. The Philippines Agroforestry Systems, 52: 207-217.

Sobral M. \& Stehmann J.R., 2009. An analysis of new angiosperm species discoveries in Brazil (19902006). Taxon, 58: 227-232.
Sodhi N.S., Posa M.R.C., Lee T.M., Bickford D., Koh L.P. \& Brook B.W., 2010. The state and conservation of Southeast Asian biodiversity. Biodiversity and Conservation, 19: 317-328.

Sohmer S.H. \& Davis A.P., 2007. The genus Psychotria (Rubiaceae) in the Philippine Archipelago. Sida, Botanical Miscellany, 27: 1-247.

Sopsop L.B. \& Buot I.E. Jr., 2013. The forest types in Aborlan Guba System, Palawan Island, Philippines. International Journal of Ecology and Conservation, 7: 88-104.

The Plant List, 2013. Version 1.1. Published on the Internet, http://www.theplantlist .org/ (accessed 10 December 2017).

UNDP, 2006. United Nations Development Programme. Community Management of Protected Areas for Conservation (Compact). Community-based initiatives to conserve biodiversity in world heritage landscapes.

USAID, 2014. Agency for International Development. https://rmportal.net/library/content/biodiversity-forestry-forestry.

Villanueva E.L.C. \& Buot I.E. Jr., 2015. Threatened Plant Species of Mindoro, Philippines. International Journal of Ecology and Conservation, 14: 168. https://doi.org/10.7718/ijec.v14i1.901

Villegas K.L. \& F.A. Pollisco Jr., 2008. Floral survey of Laiban, sub-watershed in the Sierra Madre Mountain Range in the Philippine. Journal of Tropical Biology and Conservation, $4: 1-4$.

Webb CO, Slikk JWF. \& Triono, T., 2010. Biodiversity inventory and informatics in Southeast Asia. Biodiversity Conservation 19: 955-972

Williams P., Gibbons D., Margules C., Rebelo A., Humphries C. \& Pressey R., 1996. A Comparison of Richness Hotspots, Rarity Hotspots, and Complementary Areas for Conserving Biodiversity of British Birds. Conservation Biology, 10: 155-174.

Yamamoto K. Sulaiman O., Kitingan C., Choon, Lw. \& Nhan T., 2003. Moisture distribution in stems of Acacia mangium. A. auriculiformis and hybrid Acacia trees. Japan Agriculture Research Quarterly, 37: 207-212.

Yates C.J., Robinson T., Wardell-Johnson G.W., Keppel G., Hopper S.D., Schut A.G. \& Byrne M., 2019. High species diversity and turnover in granite inselberg floras highlight the need for a conservation strategy protecting many outcrops. Ecology and Evolution, 9: 7660-7675.

https://doi.org/10.1002/ece3.5318 
. 
